\title{
The Quality of Life: Research of Urban Security Aspects
}

\author{
Jonas Jakaitis \\ Department of Design at Faculty of Architecture, Vilnius Gediminas Technical University, Lithuania
}

Copyright $(2015$ Horizon Research Publishing All rights reserved.

\begin{abstract}
The investigation is based on the basic theoretical principles and the existing practices of community involvement into urban spatial planning proses as a creator of urban public security conditions. The article explores ways of improving urban structures of residential territories especially in the aspect of the urban public security. In the 1990s, public organizations of European and other countries focused their attention on improving the quality of life in cities. Theories regarding citizens' rights to protection from aggression, environmental pollution as well as the right to shelter and safe living spaces, health care, cultural life, democratic control of authorities and participation in the development of democratic principles

possible to determine cohesion between urban indicators and safe living environment. The goal of this article is to analyse different urban structures as objects influencing the quality of life through safe living environment interfaces. Also, to introduce urban planning measures that would reduce amount of threats to public safety. The research and statistical analysis was carried out with the aid of GIS software. The results showed that urban planning as a measure of public space and architecture formation is an integral part of security control and prevention in the multifunctional urban environment. The article gives a set of recommendations on the ways of improving methods and practices of safety living environment.
\end{abstract} have been analyzed in a great number of documents from various perspectives. On the basis of Western countries experience, this article studies an impact of cities urban structure and physical environment on public safety as one of the most important quality of life indicators. Lithuanians are not the owners of their own territories (this is in the ownership of the State), i.e. private subjects like public, territorial communities and real estate developers become the initiators of urban architecture development. Therefore, the local communities themselves get strengthened by consolidating their interests towards achieving common goals in the territory of their interest. Therefore, the problem of the present investigation can be associated with the following issues: factors and circumstances that determine the transformation of urban structure include the availability of effective measures for safety living spaces, social control over developing urban architecture, increasing pollution of the environment, the ideological transformation of policies, the transformation of human attitudes and his place in the world. Safe living spaces are influenced by various factors such as IT development, globalization, increasing competition and the dynamics of activities aimed at developing urban architecture. Globalization created by the development of information technologies focuses on building a cosmopolitan global unsafely society, anonymous culture and architectural style in these areas the quality of life indicators are strongly impacting on identifying the size and the boundaries of the territory that community is interested in. In the context of such circumstances that the territorial communities' zones were formed, the author carried out a study, which made it
Keywords Urban Development, Urban Safety, Territory Community, Quality of Life, Crimes, Community, Informal Planning

\section{Introduction}

The article aims to discover and promote wider and deeper analysis of the problem of public safety as one of the most important quality of life indicators, stimulating expression of identity of territorial communities by optimisation of their formal territorial network. The problem is closely related to urban development policy which is implemented in many European countries. However, there often are political and democratic contradiction between the legal environment regulating standards and the level of quality of life perceived by residents. The results of the monitoring carried out by the United Nation in 2013 [1] shows, that in some major European cities, also including Vilnius (Fig. 1), one of critical factors affecting quality of life is an issue of public safety. It is noted, that even $31 \%$ of the respondents rated public safety as one of the greatest threats to quality of life conceding only to job creation and health services.

Lithuanian national policy guidelines [2] proclaimed that control of crimes that were committed in public places is recognized as a priority direction, and one of the tasks is the creation of safe environment in pursuance with the territory planning and urban operation. 


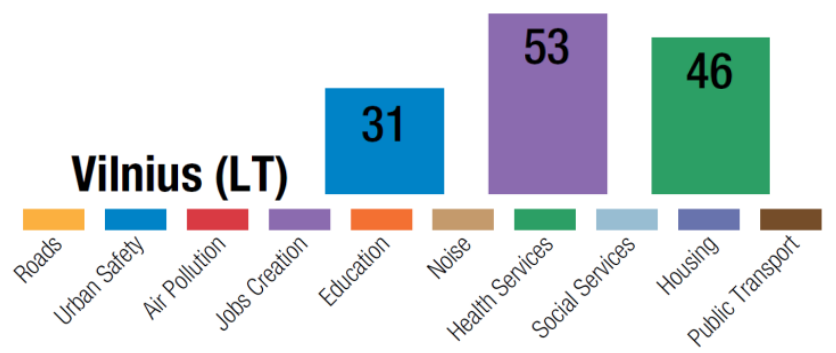

Figure 1. The great threats to the quality of life level in Vilnius (2013)

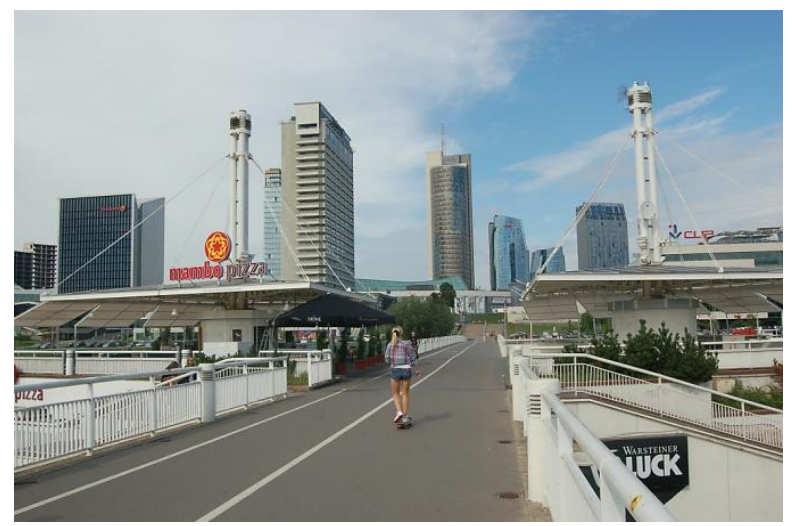

Figure 2. New architecture in Vilnius (Lithuania) as compact and safety modern administrative center

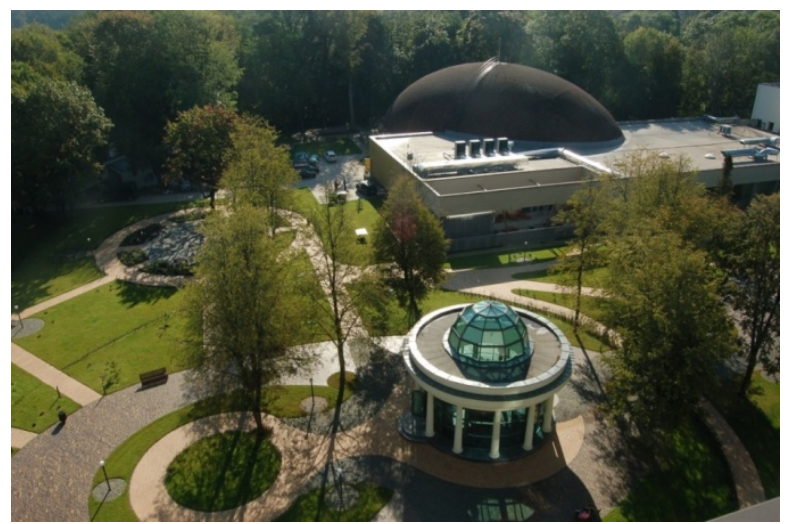

Figure 3. Unique architecture in Druskininkai (Lithuania) as compact, safety and polyfunctional modern public urban structure

As the way of living is transforming, the concept of quality of life criteria is also changing. The interests of residents in the development of their native town, the informal interaction of dynamic (active citizen participation) and static (physical architectural environment) factors are particularly important conditions of life because their reaction helps in reflecting a visual, emotional or functional meaning in the city form. Moreover, it allows residents to see the values of the town and appreciate the participation of communities in the architectural development of their own city, which therefore can help with transforming the city's image and creating unique architectural (Fig. 2; Fig. 3) features characteristic of a particular age. Well thought out citizen participation in urban development based on democratic planning principles is the only legal way for citizens to express their opinions. However, citizen participation can be effective only if the community takes the responsibility for the consequences of actions performed or decisions made by people in the planning process. Residential areas differentiate according to communities' material conditions, social society members' dependence to community-based organizations. Personal and public security is an essential state policy goal - security of constitutional human rights and freedoms - implementation condition, which partly depends on the individual city conditions.

In Lithuania and partly in Vilnius there are different territorial levels of urban communities that could be identified in urban area. Some trends of analysis are possible and the research will follow of them. Starting with a bigger side and going to a smaller, community of a complete territory could be identified in the state, regional, city, districts of city and sub districts cases the community is represented by a group of approx. 3000k of state residents, $550 \mathrm{k}$ of Vilnius City residents supplemented by almost $80 \mathrm{k}$ of suburban residents - people that associate their life with Vilnius City.

The next level down is stratus of urban residents in the big parts of the city, or so called city districts. These areas are formed historically in the informal long range of development of Vilnius City. Areas as The Old Town, The New Town, Užupis, Rasos, Šnipiškès, Žverynas and the others could be listed as a case. These areas are still big in their territories (The Old Town (450ha) (Fig. 5 (b)), Rasos (1270ha), Šnipiškès (312ha), New Town (480ha) Žverynas (270 ha)) and in the number of their residents (The Old Town (21k), The New Town (29k), Rasos (13k), Šnipiškès (20k), Žverynas (12.2k)). Territories of these city districts are mainly identified by similar environmental typology that is formed in Vilnius city. The third level down for urban community is attributed to districts territorial communities (seniūnijos) - formal units of territorial community. The fourth levels down are informal level - sub districts local territorial communities which are created not by government of city. Its informal territorial communities where every resident belong to neighborhoods in these areas the quality of life indicators have a strong impact on identifying the size and the boundaries of the territory that community is interested in. According to D. Held, 'a community should be guided by a concept of the collectively created common good'. [3] If citizens have no opportunities to actively participate and become aware of their role in the aforementioned planning process, most of them will always remain detached observers of democratic development and unable to participate in collective decision-making or discussions about the ways of creating common wealth.

The goal of this article: to analyze different urban structures as objects influencing the quality of life through safe living environment interfaces and to introduce urban planning measures, permitting the reduction of the threats to public safety; Also to analyze the level of safety in public places using a data on spatial distribution of crime events in Vilnius city. 


\section{Methodology of Research}

The problem of involving communities in sustainable development for better quality of life through safe living environment has been much discussed both on national and international scale. A resolution adopted by the Lithuanian Government 'On approving a list of fields of architecture to be developed in Lithuania' emphasizes the significant role of architecture as a unique art in the country, implying that every citizen should actively participate in architectural development. According to Bristol Accord1, the agreement adopted on the 6th -7th of December, 2005 at the informal meeting of foreign affairs ministers from $12 \mathrm{EU}$ countries, the key indicators of sustainable community were defined with the emphasis placed on the involvement of society in urban development of the border regions. Many articles and monographs published by world researchers and various specialists on this problem and plans and surveys also confirm the importance of the discussed problem such as criminologist C. Ray Jeffery termed defensible space theory that was developed concurrently by architect Oscar Newman. According to the theory, criminality can be controlled and mitigated through urban design. There are five factors that make a security space: -territoriality - the idea that one's home is sacred, -natural surveillance - the link between an area's physical characteristics and the residents' ability to see what is happening, -image - the capacity of the physical design to impart a sense of security, -milieu - other features that may affect security, such as proximity to a police substation or busy commercial area, -safe adjoining areas for better security, residents obtain higher ability of surveillance of adjoining area through designing the adjoining area. Newman in his book [4] seems to partially endorse the new urbanism theory that pedestrian traffic creates "eyes on the street" and thus enhanced security. He writes that "streets provide security in the form of prominent paths for concentrated pedestrian and vehicular movements; windows and doorways, when facing streets, extend the zone of residents' territorial commitments and allow for the continual casual surveillance by police in passing cars." This related to non-formal society activity and "informal territorial communities" self-formation. So, is important look at the city's development from a New Urbanism perspective, the new widely accepted planning paradigm in America that promotes higher density, mixed use communities based on the traditional town European models, communities in which one lives, works and plays all within a mile radius. The New Urbanism aims to create buildings, neighborhoods, and regions that provide a better quality of life for residents while limiting negative environmental and social impacts. New ideas support the revitalization of existing urban structures and the reconfiguration of suburban sprawl to create healthy and sustainable towns and cities. The problem of informal participation of society in developing urban architecture in Lithuania was also irregularly studied by various scientists such as architect $\mathrm{J}$.

1 Office of the Deputy Prime Minister. Conclusions of Bristol Ministerial Informal Meeting on Sustainable Communities in Europe. UK Presidency. Bristol, 6-7 December 2005, 19 p.
Vanagas2, anthropologist R. Vaštokas (Canadian scientist from Lithuania), sociologist A. Pociene, and theorist of architecture R. Buivydas.

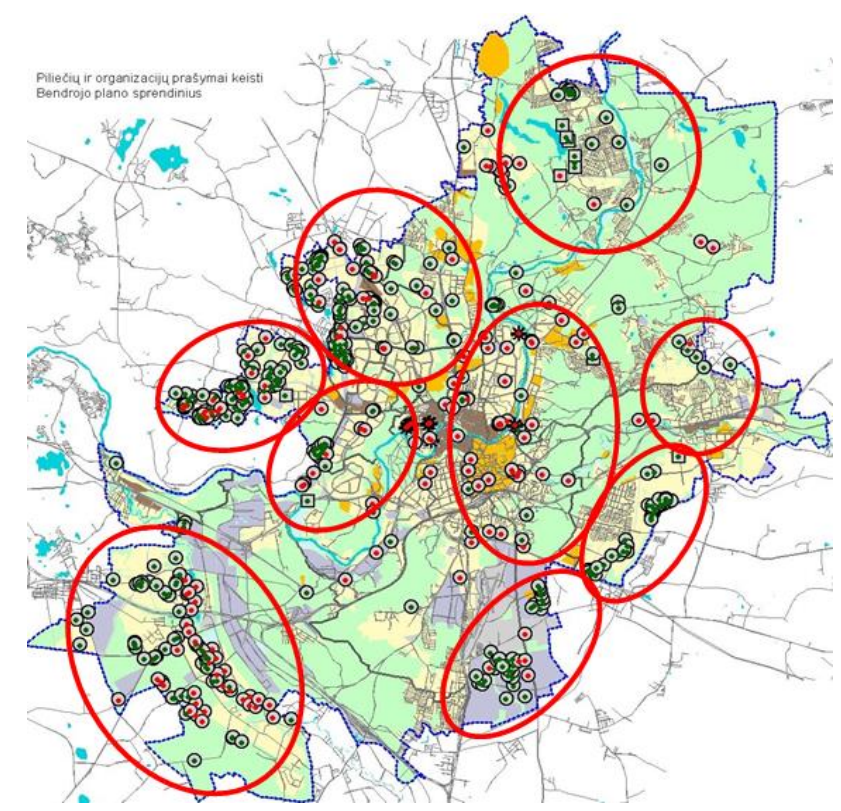

Figure 4. The network of "informal territorial communities" in Vilnius based on data collected by the author
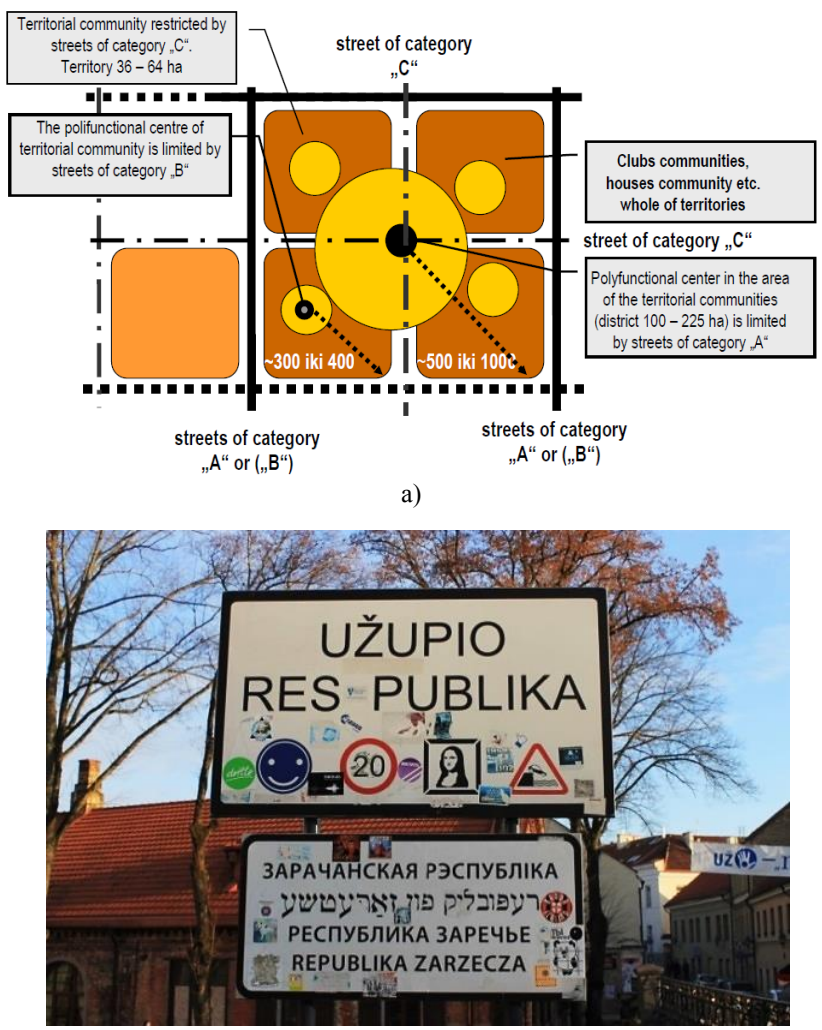

b)

Figure 5. According to research the formal model contains "informal territorial communities" (a); "informal territorial community" in Old Town of Vilnius (b)

2 Vanagas.J. 2012. From the Cave Shelter to the Modern Megalopolis. Vilnius: Technika. 

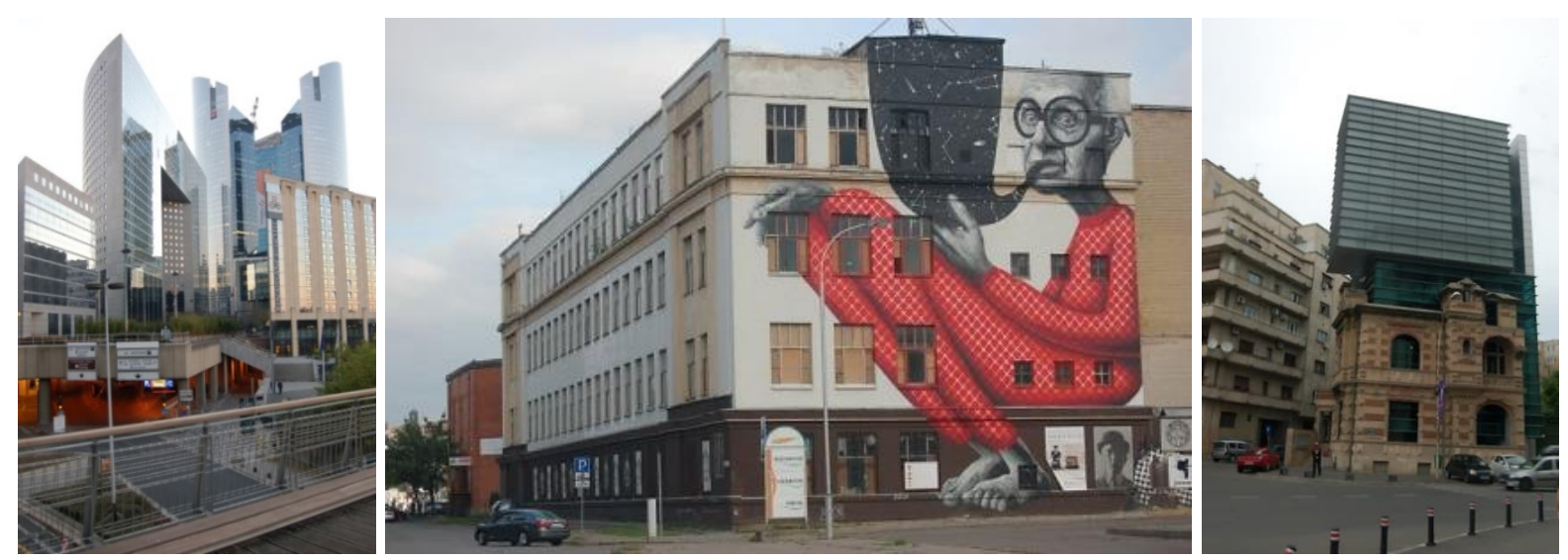

Figure 6. Unsafe and unbalanced urban environment is created for example by hyper modern architecture in Paris, by places near center of Kaunas, or by low-quality architectural in Bucharest

For investigating the problem, the author has established the laws and relationships governing citizen participation in developing urban architecture and the factors determining social activity. This allowed the author to develop the methods of creating a social activity index. It is directly related to safety in "informal territorial communities". The author's research [5] has determined that the impact of an object can be observed if it is $2 \mathrm{~km}$ away from an observer. When performing full-scale tests, the author has confirmed these results and demonstrated that an object located within an informal community territory that is considered to be their own by the community members becomes important to them if that object is in the radius of $1-2 \mathrm{~km}$ from the centre of the area. Data analysis indicates that the main principles of the architectural development of the city have not been always taken into account. However, according those factors is suggested "informal territorial communities" (Fig. 4; Fig 5).

The author makes an assumption, that the highest concentration level of public irregularities is dominated in the biggest attractions centers, public spaces and dense and heavy build-up residential areas approaches (Fig. 6) [6]. The important evaluation indicators:

1. in a monotonous altitude build up areas.

- distribution of crimes events;

- the height of building;

- the volume of buildings;.

2 . in the biggest attractions centers, public spaces and dense and heavy build-up residential areas:

- index of polycentrisim;

- density of streets;

- locations of informal territorial communities zones;

- amount of residents.

However, quality of life in the active areas of territorial communities, as well as the security of citizens is directly proportional to the compactness of the urban structures, polycentricism and public activity.

The article analyzes statistical data of various criminologist factors such as type, place, density, frequency, and urban psychology. The innovation of the article comes from the following points: 1 . taking into account that the field of public safety in respect of geographical distribution of crimes events is not yet fully explored in Lithuania scale. The results of the research is a step forward towards providing so far unusual preventive measures that will ensure reduction in level of crimes in public spaces. 2. According to the fact that only 26 percent of all crimes events are investigated in Vilnius city in few last year. All provided data can be indicated as a source of information for different public sector institutions including policy, research centers, institutes, universities, etc.

This article elaborates on some popular public safety models which came from America and could be applied in Lithuania scale evaluating its relationship to city architecture and landscape arrangement in city. The author will prove the impact of the relationship through row of researches and its analysis using statistical methods with the aid of GIS software [6].

In order to examine these hypotheses, two experiments were conducted applying qualitative methods. The authors succeeded to measure, compare and explain factors assessed in foreign countries, which were affecting the public safety in Vilnius City case (Table 2)

\section{Vilnius Example}

According to Leon Krier, an English urban planner, "Simplicity must be the goal of the urban plan, however complex the urban geography and topography. The city must be articulated into public and domestic spaces, monuments and urban fabric, classical architecture and vernacular buildings, squares and streets, and in that hierarchy." So, the investigation aims to provide a common language around the definition of best practice sustainable communities 3 , encourage innovation and excellence in the approach to creating future communities, promote integration across the field of sustainability issues related to goods of communities and provide a basis for ongoing evaluation of sustainable, safe community evolution.

3 Hansen, S. 2014. Looking to the Village for Tomorrow's City Design. E-sours: http://sourceable.net/looking-village-tomorrows-city-design/ 

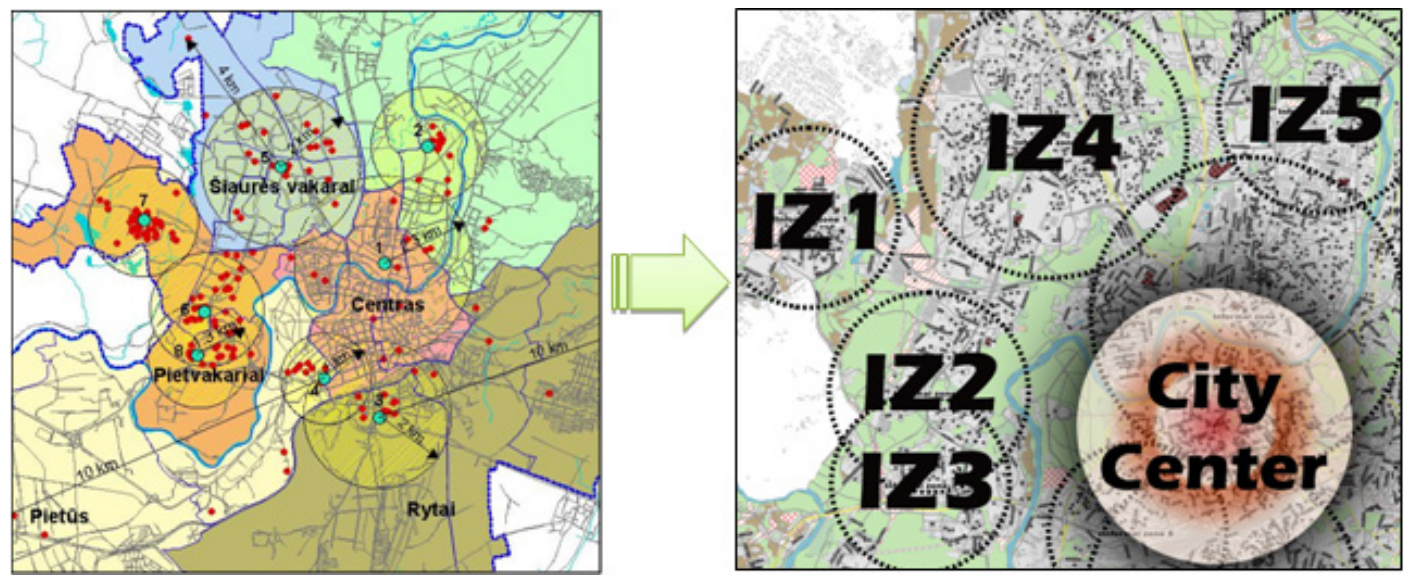

a)

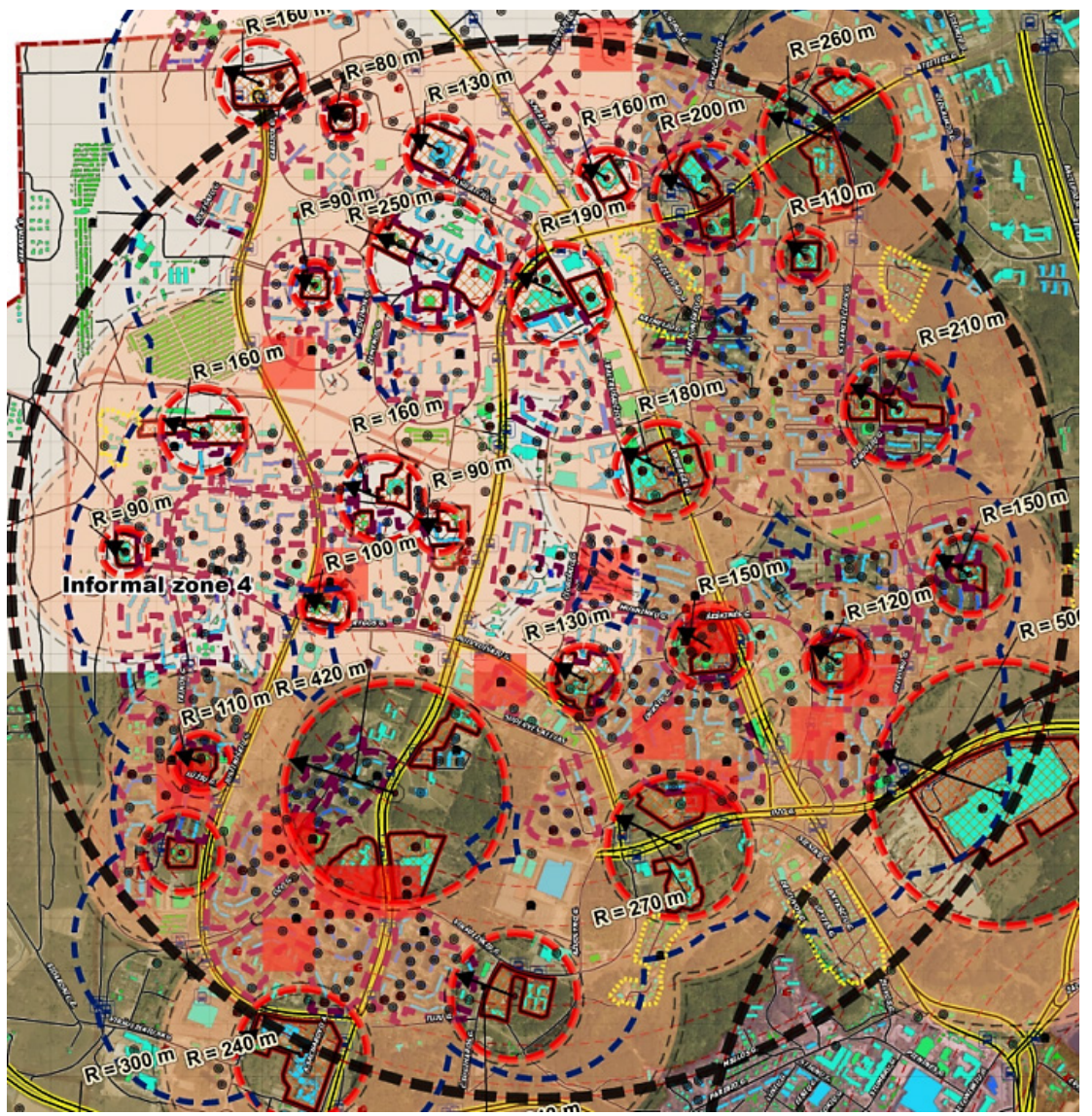

b)

- Boundaries of the informal territorial community as a special type of urban areas

Figure 7. The analysis of "informal territorial community as a special type of urban areas" network (a) and analysis of "informal zone" IZ4 (according main ideas of the author is prepared by V.Bielinskas) (b) example in Vilnius territory

First step of investigation. While conducting the study, the author identified territories, where the greatest impact on public security was made by buildings shaping the urban environment build up indicators - height, density, building intensity and area of a territory (factors that correlate with the compactness of urban structures and polyfunctionality). The calculations were carried out by grouping the spread of public order violations according to different types of buildings dislocation in Vilnius informal areas (Fig. 7). After statistical analysis the author [6] presented the investigations results.

Here are the following indicators that are derived from the study:

- the correlation coefficient of the number of crimes and build up intensity (' $r$ ' (Cr\&I. ));

- the correlation coefficient of the number of crimes and the heights (' $r$ ' $(\mathrm{Cr} . \mathrm{H} H)$ ).

The values of these indicators are presented in Table 1 . 
The results shows that in the central part of city safety is mainly influenced not by the height of the buildings, but attraction centers and public spaces that have no coherence with urban structure, that form around anonymous, easily transitive and transit territories.

Table 1. Number of crimes and build up parameters dependency in different types of urban areas

\begin{tabular}{|c|c|c|c|}
\hline & 'r' (Cr\&I.) & ' $\mathrm{r}$ ' (Cr.\&H) & disparity \\
\hline Central part of city & 0,554 & 0,274 & 0,280 \\
\hline Areas of block of flats & 0,570 & 0,545 & 0,025 \\
\hline Areas of low-rise buildings & 0,363 & 0,288 & 0,075 \\
\hline Peripheral low-urbanized areas & 0,303 & 0,131 & 0,172 \\
\hline
\end{tabular}

Territories of these city districts are mainly identified by similar environmental typology. The fourth levels is an informal level of territorial communities. In these areas the environmental factors are strongly impacting identification of the size and the boundaries of the territory that community is interested in (Table 2).

Table 2. Example of statistical analysis of data for calculation of urban area IZ4 features:

\begin{tabular}{|c|c|}
\hline I. The type of urban area IZ4: & \\
\hline $\begin{array}{l}\text { 1. Multi-function territory } \\
\text { 2. Street network density } \\
\text { 3. The gravity centers which is related to } \\
\text { multifunctional level: } \\
\text { a. shopping centers } \\
\text { b. schools } \\
\text { c. preschool education institutions } \\
\text { d. catering companies } \\
\text { e. green territory } \\
\text { f. sports grounds etc. }\end{array}$ & $\begin{array}{l}\text { multifunction } \\
\text { index - 0.34, } \\
103.0 \mathrm{~m} / \mathrm{ha} \text {, }\end{array}$ \\
\hline $\begin{array}{l}\text { II. The crime statistical analysis of data } \\
\text { /according to Lithuanian Department of } \\
\text { Statistics/: }\end{array}$ & \\
\hline $\begin{array}{l}\text { 1. Total number of crimes: } \\
\text { 1. crime number is } \\
\text { 2. scrimmage } \\
\text { 3. } \\
\text { murders }\end{array}$ & $\begin{array}{l}0.84 / \mathrm{ha} \\
0.70 / \mathrm{ha} \\
0.12 / \mathrm{ha} \\
0.02 / \mathrm{ha}\end{array}$ \\
\hline
\end{tabular}

The author found that the biggest threat to public security in the residential quarters due to environmental monitoring facilities is in the house group that is higher than 5 floors. These areas are characterized as misbalance of urban structure, architecture and community needs. This determines tenuous communal relations and decrement of responsibility for the living environment. These results are similar to analogous study results $[7 ; 8 ; 9]$ that were carried out in America, Great Britain or Australia.

Second step of investigation. In addition to the results of the first experiment, the 2 nd experiment assesses the relation between the inhabitants and the living environment, where residents are most active. [5].

$$
V=f\left(\frac{P, I, \ldots n}{T 1, T 2, \ldots T n}\right)
$$

Where are: $V$ - Index of activity of informal community; $P$ - Index of polycentric (marked as $I_{\text {poly }}$ ); I - Awareness of community; $n$ - etc.; $T 1$ Area of territory community is interested in; $T 2$ - Strategic approach of planning goals; $T_{n}$ - Building and area properties.

Communities' participants' activity index (V) directly depends on the awareness of the population and index of polycentricism $\left(I_{p o l y}\right)$. It was derived in each researched zone of informal territorial community (Fig. 7a). It helped to determine gravity centers (Fig. 7b). The rest of the calculations were performed in this context (Table 3). It is evident that the higher the density of the gravity centers, the higher the polycentrism $\left(I_{p o l y}\right)$ of the territorial community. Also, it leads to the lower probability of crime events. Polycentrism index is calculated by the following formula:

$$
I_{\text {poly }}=\frac{A_{t}}{A_{\text {total }}}
$$

$I_{\text {poly }}$ - index of polycentricism; $A_{t}$ - area used by attraction centers $4 ; A_{\text {total }}-$ total area of attraction centers including access

During the study, in each informal territory zone (Fig. 4) are [6] identified the most important centers of attraction, around which, in view of the urban environment, were determined the ranges of availability. In this range the authors evaluated values of urban structure indicators, delinquency dispersion and compared these values with each other (Table 3)

Calculations were carried out by grouping the spread of public order violations according to the different types of buildings dislocation in Vilnius city informal areas. Author presented the following statistical analysis results. It is shown that in the central part of the city safety is mainly influenced not by the height of the buildings, but attraction centers and public spaces that have no coherence with urban structure, that form around anonymous, easily transitive and transit territories.

Applying the method of statistical analysis here is presented the interplay correlation of introduced data (Table 4).

The author found, that the density of road network and polycentricism has the greatest impact on public safety, and the increasing territorial uncertainty determine the alienation growth trends. Lithuania survived such period during the Soviet times, when people were convinced that everything is common and there were no necessity to have one's own corner [5]. These circumstances informally, together with political factors, shape features of urban identity: structure, style, functional connections or social urban content and security in the system of territorial communities. 
Table 3. The derivative study data on the impact of informal communities on public security

\begin{tabular}{|c|c|c|c|c|c|c|c|c|}
\hline & \multirow{2}{*}{$\begin{array}{c}\text { Index of } \\
\text { Polycentric } \\
\left(\mathrm{I}_{\mathrm{poly}}\right)\end{array}$} & \multicolumn{2}{|c|}{ Road density $(m / h a)$} & \multicolumn{4}{|c|}{ Delinquency per 1000 inhabitants } & \\
\hline & & $\begin{array}{c}\text { Rapid-speed } \\
\text { streets }\end{array}$ & $\begin{array}{l}\text { Total } \\
\text { street }\end{array}$ & Conflicts & Fighting & Murder & Total & \\
\hline IZ 1 & 0,11 & 16,7 & 108,0 & 0,69 & 0,05 & 0,00 & 0,75 & \\
\hline IZ 2 & 0,22 & 10,4 & 71,5 & 0,84 & 0,16 & 0,10 & 1,03 & \\
\hline IZ 3 & 0,18 & 17,1 & 86,5 & 0,67 & 0,10 & 0,03 & 0,80 & \\
\hline IZ 4 & 0,34 & 24,6 & 78,4 & 0,70 & 0,12 & 0,02 & 3,66 & \\
\hline IZ 5 & 0,20 & 4,90 & 81,2 & 0,61 & 0,09 & 0,02 & 3,43 & \\
\hline
\end{tabular}

Table 4. Statistical analysis of data ( $T_{n}$ - building and area properties)

\begin{tabular}{|l|c|}
\hline \multicolumn{1}{|c|}{$\mathrm{I}_{\text {poly }}$ and total crime per 1000 inhab. } & 0,71 (strong) \\
\hline $\begin{array}{l}\text { rapid-speed roads density and total crime per } \\
1000 \text { inhab. }\end{array}$ & 0,03 (no impact) \\
\hline $\begin{array}{l}\text { total road density and total crime per } 1000 \\
\text { inhabitants }\end{array}$ & 0,41 (medium impact) \\
\hline
\end{tabular}

\section{Conclusions and Recommendations}

After evaluation of study results, statistical information and other countries practice in implementing the prevention of public safety in the cities, urban planning measures at the national level would significantly improve public safety which is one of the most important criteria of the quality of life. The research helped to identify shortcomings of the crime control and prevention in Lithuania. Crime control and prevention is still not integrated with the other social, economic and urban programs. Also, there are not enough opportunities for the formation of the informal territorial communities. Therefore, society is not supportive and initiative enough. According to the author these programs are still not a priority in Lithuania and they should be integrated with safety monitoring system: analysis, evaluation and removal of sources of the crime.

In Vilnius City urban structure as a preventive measure of landscaping and urban planning public safety, it is possible to apply the model of "informal territorial communities" defining the area, which is home to an organized, active and public-spirited community (Fig. 5). Such territories have clear boundaries and controlled access to the internal space. The results suggest that in the central part of city safety is mainly influenced not by the height of the buildings, but attraction centers and public spaces that have no coherence with urban structure, that form around anonymous, easily transitive and transit territories. (Fig. 8).

Analogous, decentralized urban environment formation model is widely applied in many German, Scandinavian and other cities of the democratic world.

Implementing the principles of sustainable development under the conditions of community participation and cooperation with local authorities, residents of the cities and towns of Lithuania can be successfully integrated into a modern, well-designed and compact, public safety urban space. Comfortable and healthy environment is a result of joint efforts, a proper choice and good projects (Fig 9).

Their uniqueness comes from a mixed build up applying a multifunctional polycentric urban structure at the same time regulating the height build up, providing sufficient community infrastructure objects and access to public goods and security.

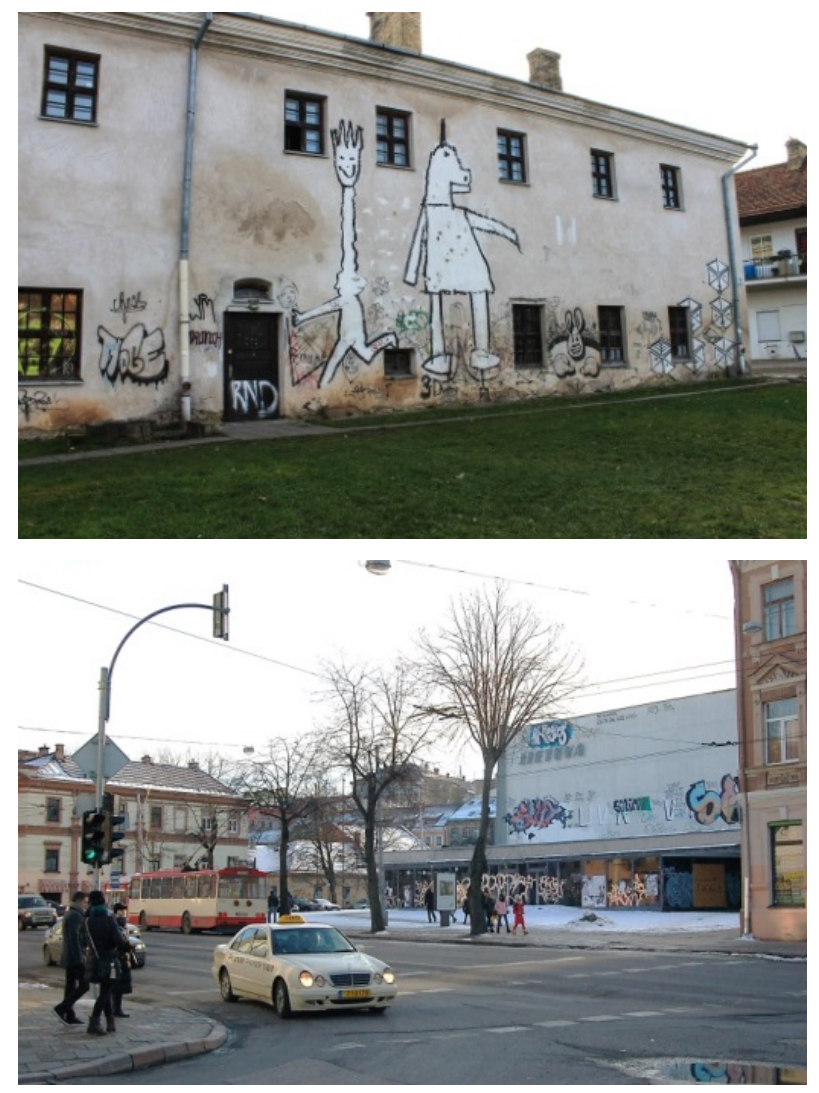

Figure 8. Unsafe and unbalanced urban environment in Old Town in Vilnius 

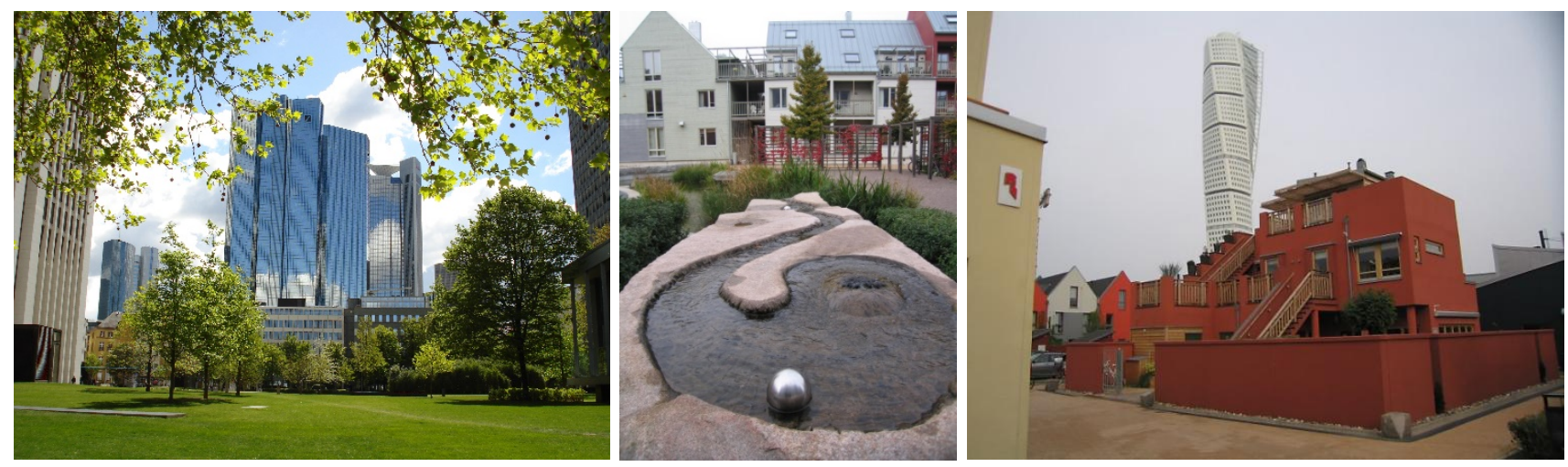

Figure 9. Frankfurt‘s (Germany) modern city center, Malmö (Sweden) compact modern building polyfunctional living district with new - formed building (unique static factor) - Turning Torso skyscraper (arch. Santiago Calatrava (2005)) which became modern architecture symbol and community identity sign not only for Malmö but and for all Sweden

\section{REFERENCES}

[1] United Nation Human Settlements Programme. State of the World's Cities 2012-2013. Prosperity of Cities. ISBN13:978-0-415-83888-7. Cambridge, UK, 2013.

[2] LR Parliament decree about approval of national prevention and inspection program of criminal activities. 2003, Vilnius, Lithuania

[3] Held, D. 1987. Models of Democracy, Polity and Stanford University Press, $321 \mathrm{p}$.

[4] Newman, O. 1972. Defensible Space: Crime Prevention Through Urban Design. New York: Macmillan.

[5] Jakaitis, J. 2013. A discourse on the members of urban spatial formation under conditions of modern democracy:

Monograph. Vilnius: Technika. 220 p. ISBN 978-609-457-475-7.

[6] Jakaitis, J.; Bielinskas, V. 2013. PUBLIC SAFETY AS A DEMOCRATIC TOWN PLANNING MEASURES RESULTS (in the context of Vilnius city) / Материалы Международной научно-практической конференции «Актуальные проблемы большого города: архитектурная теория и практика» - Алматы: КазНТУ. p. 193-196. ISBN 978-601-228-551-2

[7] Vileikienè, E. 2012. Ministry of the Interior of the Republic of Lithuania. Lithuanian population approach to public safety assessment. Vilnius. 48 p. E-sours: www.policija.lt/get.php?f.11102

[8] Jacobs, J. 1961. The Death and Life of Great American Cities. New York: Random House. 480 p. ISBN 0-679-60047-7

[9] Pociene, A. 2009. Social order and security assumptions in the city. Western experience in applying environmental criminology theories and outlook in Lithuania. Low Institute. 